CLINICAL STUDY

\title{
Activation of the erythropoietin receptor in human skeletal muscle
}

\author{
Helene Rundqvist ${ }^{1,2}$, Eric Rullman ${ }^{3, *}$, Carl Johan Sundberg ${ }^{1, *}$, Helene Fischer ${ }^{3}$, Katarina Eisleitner ${ }^{1}$, \\ Marcus Ståhlberg ${ }^{4}$, Patrik Sundblad ${ }^{3}$, Eva Jansson ${ }^{3}$ and Thomas Gustafsson ${ }^{3}$ \\ ${ }^{1}$ Section of Molecular Exercise Physiology, Department of Physiology and Pharmacology, ${ }^{2}$ Department of Cell and Molecular Biology and ${ }^{3}$ Division of \\ Clinical Physiology, Department of Laboratory Medicine, Karolinska Institutet, 17177 Stockholm, Sweden and ${ }^{4}$ Department of Medicine, Karolinska \\ University Hospital, Stockholm, Sweden \\ (Correspondence should be addressed to H Rundqvist at Section of Molecular Exercise Physiology, Department of Physiology and Pharmacology, Karolinska \\ Institutet; Email: helene.rundqvist@ki.se)
}

*(E Rullman and C J Sundberg contributed equally to this work)

\begin{abstract}
Objective: Erythropoietin receptor (EPOR) expression in non-hematological tissues has been shown to be activated by locally produced and/or systemically delivered EPO. Improved oxygen homeostasis, a well-established consequence of EPOR activation, is very important for human skeletal muscle performance. In the present study we investigate whether human skeletal muscle fibers and satellite cells express EPOR and if it is activated by exercise.

Design and methods: Ten healthy males performed 65 min of cycle exercise. Biopsies were obtained from the vastus lateralis muscle and femoral arterio-venous differences in EPO concentrations were estimated. Results: The EPOR protein was localized in areas corresponding to the sarcolemma and capillaries. Laser dissection identified EPOR mRNA expression in muscle fibers. Also, EPOR mRNA and protein were both detected in human skeletal muscle satellite cells. In the initial part of the exercise bout there was a release of EPO from the exercising leg to the circulation, possibly corresponding to an increased bioavailability of EPO. After exercise, EPOR mRNA and EPOR-associated JAK2 phosphorylation were increased. Conclusions: Interaction with JAK2 is required for EPOR signaling and the increase found in phosphorylation is therefore closely linked to the activation of EPOR. The receptor activation by acute exercise suggests that signaling through EPOR is involved in exercise-induced skeletal muscle adaptation, thus extending the biological role of EPO into the skeletal muscle.
\end{abstract}

European Journal of Endocrinology $161427-434$

\section{Introduction}

The human body exhibits a significant capacity to adapt to changes in the surrounding milieu. This is exemplified by the wide range of responses at the systemic, local, and cellular levels induced by higher energy demand of the muscle during exercise, aimed to restore oxygen homeostasis. A key factor in this process is the hormone erythropoietin (EPO), mostly known for its role in promoting erythrocyte proliferation and differentiation $(1,2)$. The EPO receptor (EPOR) is known also to be expressed in the heart, uterus, and brain, which show biological responses following receptor activation (3-5). Distinguishing features of EPOR activation in peripheral tissues are various aspects of oxygen homeostasis such as capillary formation (angiogenesis) and protection against oxidative stress. Activation of EPOR results in receptor dimerization, increased affinity for JAK2 and subsequent phosphorylation of tyrosine residues on the cytoplasmic region of the receptor $(2,4,6)$. This provides docking sites for STAT
5, RAS/MAPK, and phosphatidylinositol 3-kinase (PI3K)/Akt signaling pathways, which mediate the peripheral effects of receptor activation. An additional suggested mechanism for how EPOR activation (7) may mediate tissue protective effects is through interaction with the common $\beta$ receptor $(\beta c R)$ subunit $(8)$, also known as CD131.

A well-characterized response to regular endurance training is increased angiogenesis in the skeletal muscle (9-11). It is also becoming clear that individuals who engage in prolonged endurance exercise are more resistant to oxidative stress through an enhanced antioxidant defense system $(12,13)$. Whether EPOR is activated by exercise has, to our knowledge, not been elucidated. However, endurance exercise increases serum levels of EPO (14-16) and the cellular effects induced by EPOR activation in other models are similar to those shown to be of importance in skeletal muscle adaptation to exercise. Thus, exercise induced activation of EPOR is a plausible hypothesis. 
Skeletal muscle tissue is dominated volumetrically by muscle cells, but it also contains other undifferentiated and differentiated cells, which may express EPOR. Receptor expression has been demonstrated in cultured $\mathrm{C} 2 \mathrm{C} 12$ cells (17) and in the capillary region and at the sarcolemma in cross sections of human muscle biopsies (18). However, several other cell types, such as satellite and immunological cells, lie in or adjacent to the capillary region. Thus, a more specific analysis of the cellular localization of EPOR is needed, as it would give better insight into the possible biological effects following EPOR activation in skeletal muscle.

Here, we confirmed the muscular origin of the receptor and investigated if physical exercise activates EPOR and if there is an interaction of this receptor with $\beta c R$ in skeletal muscle tissue. We concentrated on two cell types known to be involved in skeletal muscle remodeling: satellite cells (myoblasts) and skeletal muscle fibers. Using several different laboratory methods, we found that both cell types express EPOR but not $\beta c R$ and that a single bout of exercise activates the receptor. These findings support the idea that the EPO signaling pathway is involved in human skeletal muscle adaptation to exercise.

\section{Methods}

\section{Experimental model}

Ten healthy male subjects were included in the study. Their median (range) age, height, and weight were 25 (18-37) years, $180(170-190) \mathrm{cm}$, and $77(58-82) \mathrm{kg}$ respectively. Median (range) maximal oxygen uptake $\left(\mathrm{VO}_{2 \max }\right)$ determined prior to the experiments was 3.7 (3.1-4.3) $\mathrm{l} / \mathrm{min}$. The exercise was performed on an electro-dynamically loaded cycle ergometer. The subjects performed $60 \mathrm{~min}$ of exercise. For the first $20 \mathrm{~min}$, subjects cycled at 60 r.p.m. at a median (range) work rate of 125 (105-148) W, chosen to correspond to $50 \%$ of $\mathrm{VO}_{2 \max }$, after which the work rate was increased to $165(138-195) \mathrm{W}$, corresponding to $65 \%$ of $\mathrm{VO}_{2 \max }$ for another $40 \mathrm{~min}$.

Teflon catheters were inserted into both femoral veins (FVs) and the femoral artery (FA) at the level of the inguinal ligament. Blood samples were drawn simultaneously from the FA and the ipsilateral FV, at rest, at 7,27 , and $57 \mathrm{~min}$ of exercise, as well as at $120 \mathrm{~min}$ after the end of exercise. All blood samples were collected in serum vacuum holders, centrifuged, put on ice within $10 \mathrm{~min}$, and stored at $-80{ }^{\circ} \mathrm{C}$ until further analysis. Muscle biopsies samples were obtained, using the percutaneous needle biopsy technique, from the vastus lateralis muscle of one leg at rest, immediately after exercise and 120 min after the end of exercise. All biopsy samples were frozen within $10-15 \mathrm{~s}$ in liquid nitrogen and stored at $-80{ }^{\circ} \mathrm{C}$ until further analysis. Prior to the study, the experimental protocol was explained to all subjects and informed consent was obtained. The study was approved by the Ethics Committee at Karolinska Institutet and conformed to the Declaration of Helsinki.

\section{Extraction of human satellite cells, laser-capture and micro dissection}

Human satellite cells The satellite cells were extracted from fresh muscle. Immediately following the biopsy procedure $\sim 100 \mathrm{mg}$ of muscle tissue was placed in sterile PBS containing $1 \%$ streptomycin in $4{ }^{\circ} \mathrm{C}$ overnight. The sample was incubated in $5 \mathrm{ml} 0.25 \%$ Trypsin EDTA in $37^{\circ} \mathrm{C}, 5 \% \mathrm{CO}_{2}$ with gentle agitation for 20 min. Undigested tissue was allowed to settle for $5 \mathrm{~min}$ and the supernatant was collected in $5 \mathrm{ml}$ DMEM-F12, with $20 \%$ FCS and $1 \%$ penicillin streptomycin. The cells were cultured until reaching $60 \%$ confluence. For immunofluoroscence the cells were seeded onto cover glass in 6-well plates around 40000 cells in $2 \mathrm{ml}$ medium.

Laser capture and microdissection Cross-sections $(8 \mu \mathrm{m})$ of biopsy samples were cut at $-20^{\circ} \mathrm{C}$, placed on glass slides and immediately put in cold acetone for $5 \mathrm{~min}$ for fixation, followed by washing in PBS, $3 \times 15 \mathrm{~min}$. To prevent RNA degradation, RNAase inhibitor was added to the PBS solutions $(50 \mathrm{U} / 100 \mu \mathrm{l}$; SUPERaseIn, Ambion, Foster City, CA, USA). The laser capture and microdissection were performed using the P.A.L.M system (Carl Zeiss Micro Imaging, Jena, Germany). After capturing the sum of 100 muscle fibers and subsequently an area of tissue of the same size as the fibers from each section, the caps were inserted into $0.5 \mathrm{ml}$ microcentrifuge tubes filled with $50 \mu \mathrm{l}$ of extraction buffer (PicoPure RNA isolation kit; Arcturus Engineering, Mountain View, CA, USA).

\section{mRNA}

Muscle biopsies and satellite cells Total RNA was prepared by the Trizol method (Invitrogen) and quantified spectrophotometrically by absorbance at $260 \mathrm{~nm}$. Integrity of total RNA was determined by $1 \%$ agarose gel electrophoresis.

Cells from laser capture and microdissection Total RNA was extracted from the cell lysate using the PicoPure RNA isolation kit according to the manufacturer's protocol (PicoPure RNA Isolation Kit, Arcturus Engineering). Isolated RNA was reverse transcribed by superscript reverse transcriptase (Life Technologies, Gaithersburg, MD, USA) using random hexamer primers (Roche Diagnostics). Detection of mRNA was performed on an ABI-PRISM 7700 sequence detector (Applied Biosystems, Foster City, CA, USA). Oligonucleotide primers and TaqMan probes were designed by using 
Primer Express version 1.0 (written in the $5^{\prime}$ to $3^{\prime}$ direction, EPO forward direction, GCCAAGGAGGCCGAGAA; reversed direction, TAACTTTGGTGTCTG GGACAGTGATA; and probe, ATCACGACGGGCTGTGCTGA ACACT). Vascular endothelial growth factor (VEGF)-A were: forward direction, ACTGCCATCCAATCGAGACC; reverse direction, GAT GGCTTGAAGAGTACTCGATCT; and probe, TGGTGGACATCTTCCAGGAG TACCCTGA. The $5^{\prime}$ label was FAM, and the $3^{\prime}$ label was TAMRA or dark quencher. The probes were designed to cover exon-exon boundaries to avoid amplification of genomic DNA. EPOR and $\beta c R$ were ordered as gene assays on demand (EPOR Hs00181092_m1, $\beta \mathrm{cR}$ Hs00166144_m1; Applied Biosystems). As an endogenous control, 18S rRNA was selected to correct for potential variations in RNA loading (4310893E, Applied Biosystems). mRNA from human heart was used as a positive control for $\beta c R$ analyses. For all genes, samples were amplified simultaneously in duplicate in one assay run.

\section{Muscle EPO and EPOR protein expression}

EPO Part of the skeletal muscle biopsy was homogenized in ice-cooled buffer $(40 \mu \mathrm{l}$ buffer $/ \mathrm{mg}$ wet muscle) containing $0.1 \mathrm{M}$ potassium phosphate $(\mathrm{pH}$ 7.7), $0.05 \%$ BSA, $20 \mu \mathrm{g} / \mathrm{ml}$ leupeptin, $50 \mu \mathrm{g} / \mathrm{ml}$ aprotinin, and $40 \mu \mathrm{g} / \mathrm{ml}$ phenylmethylsulphonyl fluoride (PMSF). The homogenate was rotated for $60 \mathrm{~min}$ at $4{ }^{\circ} \mathrm{C}$ and centrifuged at $15000 \mathrm{~g}$ for $10 \mathrm{~min}$ at $4{ }^{\circ} \mathrm{C}$. For quantification of EPO protein by sandwich enzyme-linked immunoassay, $100 \mu \mathrm{l}$ of $1: 10$ diluted supernatant was used (Quantikine R\&D Systems, Minneapolis, MN, USA). Optical density was quantified on a micro plate-reader *Quant (Bio-Tek Instruments, Winooski, VT, USA). All techniques and materials used in this analysis were in accordance with the provided protocol from the company. All samples were assayed in duplicate.

EPOR and $\beta \boldsymbol{c R}$ Part of the skeletal muscle biopsy was homogenized in a buffer $(40 \mu \mathrm{l}$ buffer $/ \mathrm{mg}$ wet muscle) $20 \mathrm{mM}$ HEPES, $1 \mathrm{mM}$ EDTA, $10 \mathrm{mM} \mathrm{MgCl}_{2}$, $50 \mathrm{mM}$ $\beta$-glycerol phosphate, $1 \mathrm{mM} \mathrm{Na} \mathrm{VO}_{4}, 2 \mathrm{mM}$ dithiothreitol (DTT), $500 \mu \mathrm{l} 1 \%$ Triton X-100, $5 \mathrm{mM} \mathrm{EGTA,}$ $20 \mu \mathrm{g} / \mathrm{ml}$ leupeptin, $50 \mu \mathrm{g} / \mathrm{ml}$ aprotinin, $40 \mu \mathrm{g} / \mathrm{ml}$ PMSF. The homogenate was incubated for $30 \mathrm{~min}$ in $4{ }^{\circ} \mathrm{C}$ followed by centrifugation at $10000 \mathrm{~g}$ for $10 \mathrm{~min}$ at $4{ }^{\circ} \mathrm{C}$ and collection of the supernatants. The protein content was determined by Bradford assay using BSA as a standard. Muscle homogenate was separated on a $10 \%$ SDS-polyacrylamide gel $(50 \mu \mathrm{g}$ of protein per lane). The proteins were blotted onto Protran nitrocellulose membranes (Schleicher \& Schnell, Germany). The membranes were incubated over night at $4{ }^{\circ} \mathrm{C}$ with either the polyclonal antibody against EPOR from rabbit (SC-695 Santa Cruz Biotechnology, Santa Cruz, CA,
USA) diluted 1:1000 with 1\% milk in Tris buffered saline-tween 20 (TBST), with the monoclonal antiEPOR antibody from mouse (R\&D Systems, MAB287) or the rabbit polyclonal anti $\beta c R$ antibody (K17, Santa Cruz Biotechnology) diluted 1:1000 with 1\% milk in TBST. HRP-linked anti-rabbit antibody (Cell Signaling, Beverele, MA, USA) diluted 1:2000 in TBST or HRPlinked anti-mouse antibody (Cell Signaling) diluted 1:10 000 for $60 \mathrm{~min}$ at room temperature was used as secondary antibody. For detection of the immunocomplex the chemiluminescense (ECL) system (Amersham Biosciences, London, UK) was used according to the manufacturer's protocol.

\section{Immunoprecipitation of EPOR}

Part of the muscle protein homogenate was pre-cleared of nonspecific precipitation species, through incubation of muscle protein homogenate $(200 \mu \mathrm{g})$ with $5 \mu \mathrm{l}$ of preimmune rabbit antiserum (Abcam, Cambridge, UK) and $30 \mu \mathrm{l}$ of BSA-coated protein A-sepharose beads (GE Healthcare, Milwaukee, WI, USA; 50\% slurry in $20 \mathrm{mM}$ Tris-HCl (pH 7.4), 1 mM EDTA, 10\% (wt/vol) glycerol, $1 \mathrm{mM}$ DTT, $150 \mathrm{mM} \mathrm{NaCl}, 0.1 \%$ Triton X-100) followed by centrifugation at $1000 \mathrm{~g}$ for $5 \mathrm{~min}$ at $4{ }^{\circ} \mathrm{C}$. Supernatant was transferred to fresh tubes and incubated with $5 \mu \mathrm{l}$ of anti-EpoR rabbit polyclonal antiserum (Santa Cruz Biotechnology) for $1 \mathrm{~h}$ at room temperature. To this, $30 \mu \mathrm{l}$ of $50 \%$ slurry of protein A-sepharose beads was added and incubated with rotation for $30 \mathrm{~min}$ at $4{ }^{\circ} \mathrm{C}$. Immunocomplex bound to the sepharose beads was recovered by centrifugation at $1000 \boldsymbol{g}$ for $5 \mathrm{~min}$ and the precipitant was washed five times with washing buffer. The pellet, after final washing, was boiled in $30 \mu \mathrm{l}$ sample buffer centrifugated at $17000 \boldsymbol{g}$ for $5 \mathrm{~min}$, and the supernatant was subjected to immunoblot analysis using (1:2000) antiphosphotyrosine antibody (Millipore, Madison, WI, USA) or anti-JAK2 antibody (Millipore).

\section{EPOR protein Iocalization}

Cross sections $(8 \mu \mathrm{m})$ of muscle biopsy samples were cut at $-20{ }^{\circ} \mathrm{C}$, placed on glass slides and immediately put in ice-cold acetone for $10 \mathrm{~min}$ for fixation. After incubation with PBS containing 3\% BSA for $1 \mathrm{~h}$ at room temperature, a murine anti-human EPOR antibody (R\&D Systems, Inc.) diluted 1:40 and a rabbit anti-human Collagen IV (R\&D Systems, Inc.) diluted 1:400 in PBS with 1\% BSA was applied to the sections and incubated for $30 \mathrm{~min}$ at $37^{\circ} \mathrm{C}$. Subsequently, the sections were incubated with a FITC-conjugated anti-mouse (for EPOR) and a rhodamine-conjugated anti-rabbit (for collagen IV) secondary antibody (Jackson ImmunoResearch Laboratories, USA), both diluted 1:100 in PBS with $1 \%$ BSA for $30 \mathrm{~min}$ at $37^{\circ} \mathrm{C}$. The satellite cells were fixated in $4 \%$ formaldehyde in phosphate buffer and stained with the primary 
antibodies for EPOR (R\&D Systems Inc.) 1:20-1:50. To ensure that cells which stained for EPOR were myocytes, as myogenic control, the cells were stained with desmin, 1:75 (Abcam) in PBS with 0.002\% BSA. The secondary antibody used was anti-mouse fluorescein (FITC), 1:100 (Jackson ImmunoResearch Lab.) in $\mathrm{PBS}$ with $0.002 \% \mathrm{BSA}$, and anti-rabbit rhodamin 1:100 (Jackson ImmunoResearch Lab.) respectively. Nuclei were stained with DAPI and the cover glass were mounted on glass slides with Vectashield (Vector Lab., Burlingame, CA, USA). As a negative control for both the cross-sectional and satellite cells, the primary antibody was excluded from the protocol or replaced by mouse serum.

\section{EPO serum levels}

Quantification of EPO serum levels were performed by sandwich ELISA (Quantikine R\&D systems) as described for tissue EPO. All techniques and materials used in this analysis were in accordance with the provided protocol from the company. Serum albumin was analyzed at the Karolinska University laboratory by conventional modular P2 technique.

\section{Statistical analysis and calculations}

Data are shown as means \pm s.D. unless otherwise stated. A one-way ANOVA for repeated measures was used to evaluate the effect of exercise changes in serum concentration over time. If significance was indicated, a planned comparison was used as post hoc test. Paired Student's $t$-test was used to evaluate the effect of exercise on skeletal muscle mRNA and protein expression and compare arterial and venous EPO serum levels at each sampling time. $P<0.05$ was considered significant.

\section{Results}

\section{EPOR expression}

EPOR mRNA transcript was detected in RNA extracted from the muscle biopsy, in isolated muscle fiber material obtained by laser dissection or from extracted human satellite cells (Figs 1A-D and 2B). Two different antibodies were used for detection by immunoblot analyses of the EPOR protein: both approaches confirmed skeletal muscle EPOR expression with expected protein size (Fig. 3A). EPOR protein was localized on cross sections of the whole muscle biopsy in regions corresponding to the skeletal muscle cell membrane (sarcolemma), based on the clear co-localization with collagen IV, and in regions corresponding to capillaries (Fig. 3B-D). Co-staining of desmin, a marker for myogenic cells, and EPOR was observed on the cells extracted from the muscle biopsy (Fig. 3E and $\mathrm{F}$ ). No $\beta \mathrm{cR}$ mRNA or protein was found in skeletal muscle biopsies or satellite cells. To ensure that primers were accurate, human heart RNA was used as a positive control in which mRNA was detected (data not shown).

\section{Exercise activation of EPOR}

Immunoprecipitation of EPOR from whole muscle biopsy homogenate demonstrated phosphorylated tyrosine residues in the resting state as well as after a single exercise bout (Fig. 2A). Co-precipitated with EPOR was a $130 \mathrm{kDa}$ protein with size corresponding to JAK2; this signal was stronger after exercise (Fig. 2A). EPOR mRNA levels were higher 120 min after exercise compared with pre-exercise levels and remained elevated (Fig. 2B). Also, $120 \mathrm{~min}$ after exercise, the mRNA levels of the downstream target gene angiogenic factor VEGF-A was increased (Fig. 2C).
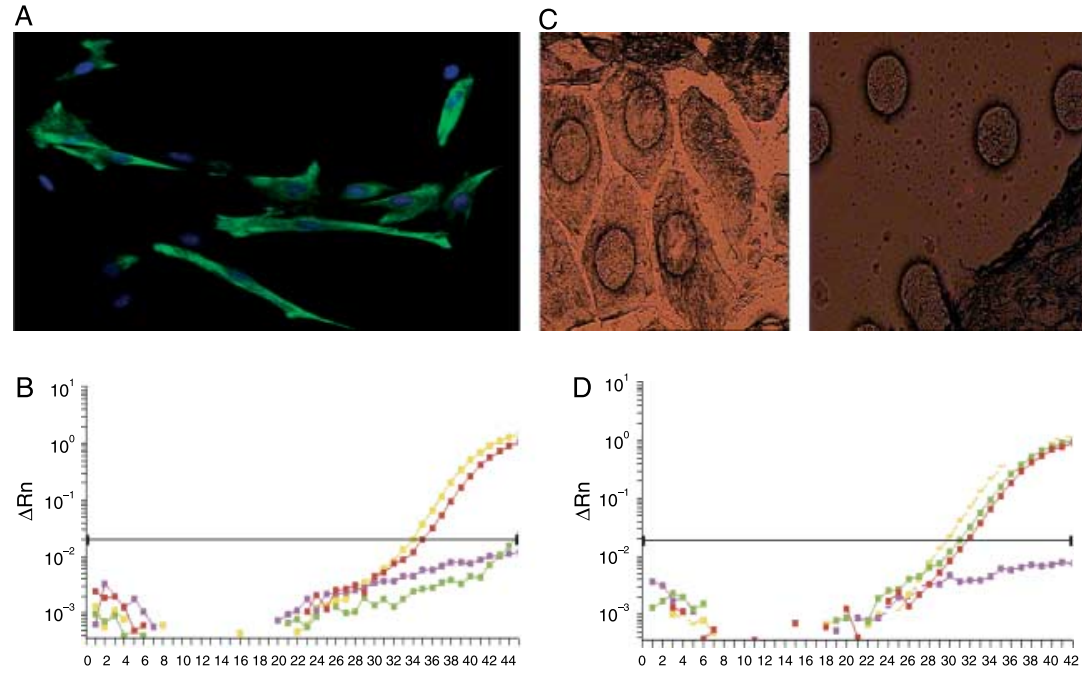

Figure 1 EPOR mRNA expression in extracted human satellite cells and microdissected muscle fibers. (A) Cells extracted from human muscle biopsies were immunostained for desmin to confirm cellular identity. Cells culture was only included if $>70 \%$ of the cells were desmin positive. (C) Principle of laser capture and microdissection of the muscle fibers: note the care taken not to include endothelial cells or other cells from the extracellular matrix. (B and D) Real time PCR measurement of EPOR gene expression from RNA extracted from laser dissected myofibres and from human satellite cells respectively. Each line represents an individual sample. Lines below threshold level, represented by the black line, are no-template controls. 

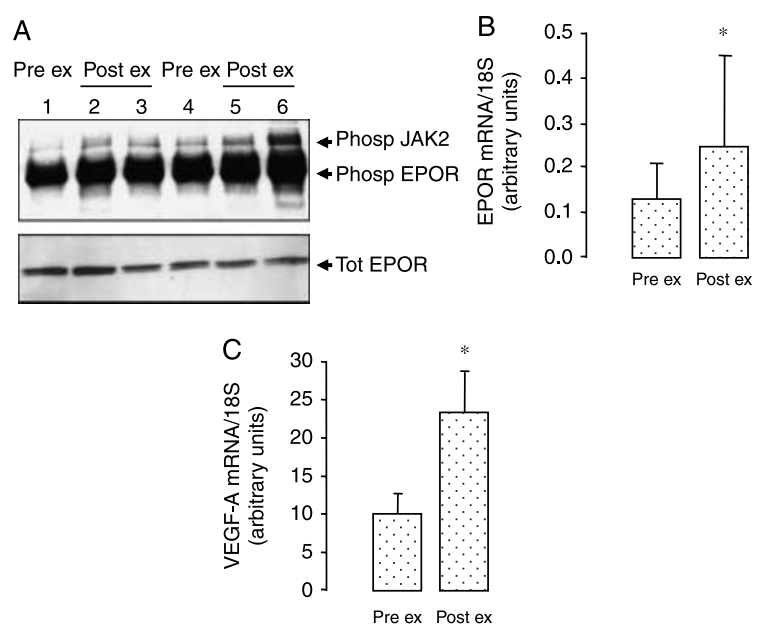

Figure 2 EPOR activation in human skeletal muscle. (A) Immunoprecipitated EPOR (lower band) and co-precipitated JAK2 detected with antiphosphotyrosine antibody (Millipore, Madison, WI, USA) and total EPOR protein. mRNA expression of (B) EPOR and (C) VEGF-A in the skeletal muscle tissue obtained before and $120 \mathrm{~min}$ after exercise. ${ }^{*} P<0.05$ compared with before exercise. Values are presented as mean \pm s.D. $(n=10)$.

\section{EPO levels}

No changes in EPO mRNA or protein content could be detected in the skeletal muscle following exercise (Fig. 4A and B). At rest, there was uptake of EPO from the circulation to the leg (arterial EPO concentration was significantly higher than the venous EPO concentration, $P<0.05$; Fig. 4 C). At exercise time points of 7 and $27 \mathrm{~min}$ there was a release of EPO from the leg to the blood (arterial EPO concentration was significantly lower than the venous EPO concentration,
$P<0.05)$ and the venous serum EPO concentration was significantly higher than pre-exercise (data not shown). No significant change was observed in arterial EPO levels during exercise. At the end of the exercise, no release was observed but a tendency to an uptake of EPO from the circulation $(P=0.08)$. To correct for hemoconcentration effects on EPO levels, arterial and venous serum albumin concentrations were measured. Correction for the significant arterio-venous albumin concentration difference after $7 \mathrm{~min}$ of exercise did not alter the significant release during exercise. Both arterial and venous EPO concentrations were significantly lower 120 min after exercise compared with pre-exercise values $(P<0.05)$ without any difference between the two. The serum EPO concentration differed between individuals but the concentration at rest did not influence the observed changes in EPO concentration with exercise.

\section{Discussion}

We found that human skeletal muscle expressed EPOR at both the mRNA and protein levels. The specificity of available EPOR antibodies has earlier been criticized, which is why we used two different antibodies for detection of the EPOR protein. Both antibodies confirmed skeletal muscle EPOR production at the expected protein size. Similar to the present study, the receptor has earlier been reported to be expressed in regions corresponding to the sarcolemma and in capillaries (18). Here, we established that both microdissected adult human skeletal muscle fibers and cultured satellite cells extracted from muscle biopsies expressed EPOR mRNA. Furthermore, muscle cross sections as well as satellite
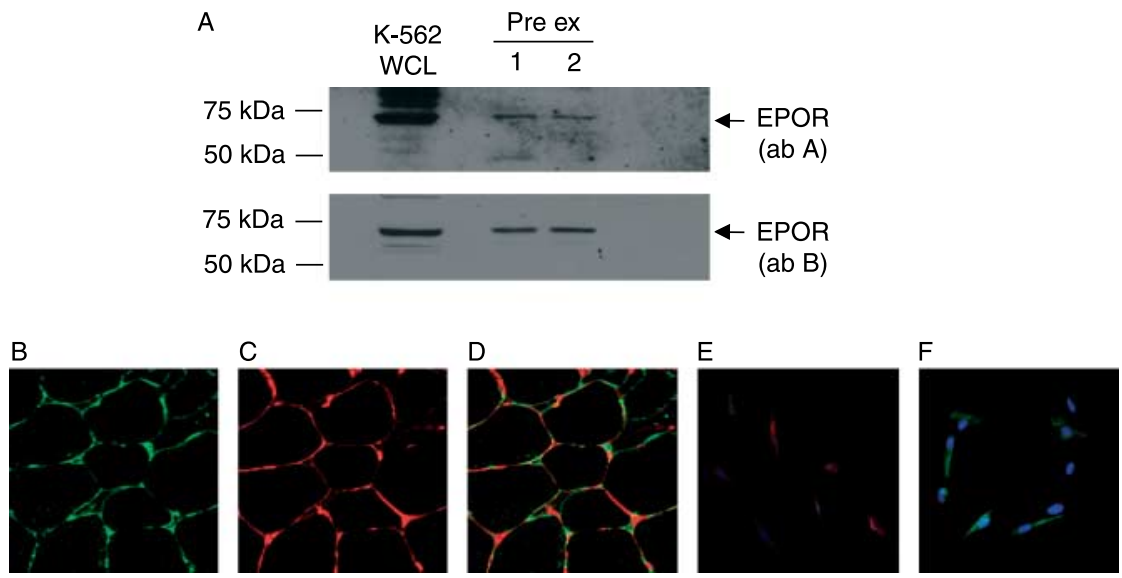

Figure 3 EPOR protein levels in human skeletal muscle. (A) Immunoblot analyses of EPOR levels before exercise ('pre ex') in two subjects. The upper lane shows EPOR detected with a murine MAB against human EPOR protein (R\&D Systems). The lower lane shows EPOR detected with a rabbit polyclonal antibody against human EPOR (Santa Cruz Biotechnology). Whole cell extracts from K-562 cells (Santa Cruz Biotechnology) were used as a positive control. (B-D) Immunohistochemical staining of muscle cross sections. (B) EPOR protein. (C) Collagen IV protein. (D) Merged image of EPOR and collagen IV proteins. (E and F) Staining of human satellite cells showing expression of EPOR (rhodamine, red) and myogenic control desmin (FITC, green). 

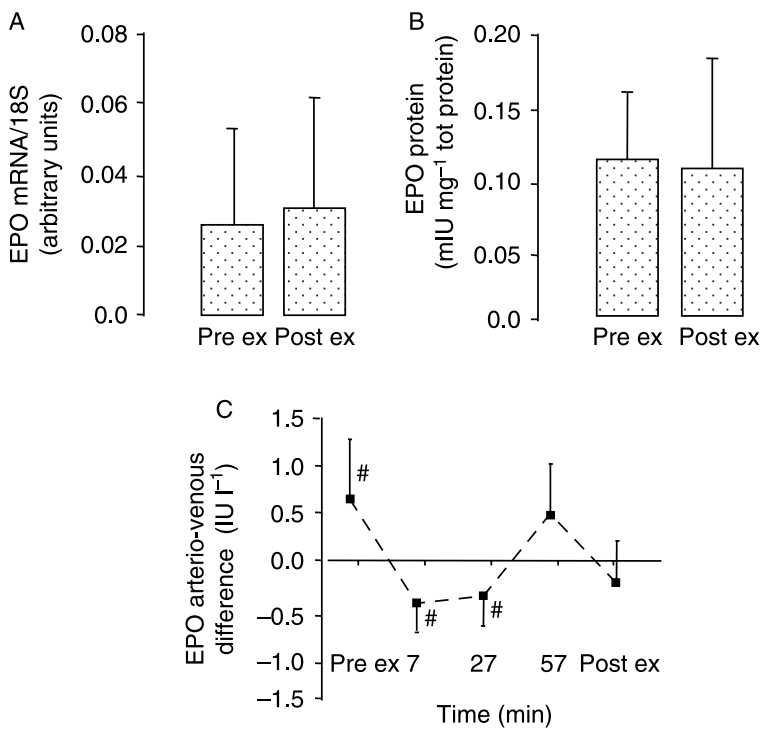

Figure 4 EPO mRNA and protein in human skeletal muscle and serum. (A) mRNA expression of EPO mRNA in skeletal muscle tissue obtained before and $120 \mathrm{~min}$ after exercise. (B) ELISA analyses of EPO protein levels in skeletal muscle tissue obtained before and $120 \mathrm{~min}$ after exercise. (C) EPO arterio-venous differences before ('pre ex'), during and after exercise ('post ex'). \#Depicts significant difference $(P<0.05)$ between arterial and venous EPO concentrations. Values are means \pm s.D. $(n=10)$.

cells stained positive for the receptor and double staining of EPOR and collagen IV in muscle cross sections demonstrated co-expression, verifying the sarcolemmal or basal membrane localization.

It should be noted that the RNA prepared from whole muscle biopsies contained von Willebrand factor (data not shown) and that capillaries stained positive for EPOR in our muscle cross sections, suggesting that endothelial cells contributed to the extracted RNA and protein. Endothelial cell EPOR expression has been shown previously (19). Thus, many of the major cell types involved in human skeletal muscle remodeling express EPOR.

A basal uptake of EPO was observed in the resting skeletal muscle, in which phosphorylated tyrosine residues on the EPOR also were detected, indicating a basal activation of the receptor. Association with JAK2 is required for EPOR signaling as it phosphorylates tyrosine residues at the docking sites for downstream signaling pathways: STAT5, the AKT pathway and the PI3K pathway $(2,4,6)$. In the present study, the pulldown assay made it possible to identify the fraction of JAK2 associated physically with EPOR. The increased phosphorylation of JAK2 seen with exercise is thereby linked to an exercise-induced activation of EPOR indicating that a single bout of exercise can activate the EPOR. In rat heart, protection against ischemia following EPOR activation has been suggested to be mediated through a heteroreceptor of EPOR and $\beta c R$ (7). In the current study no evidence of skeletal muscle $\beta c \mathrm{R}$ expression was found. This suggests that exercise induced activation of EPOR in human skeletal muscle is not dependent on heteroreceptor formation but rather on EPOR homodimerization.

In contrast to the situation in resting muscle, a release of EPO was observed from the skeletal muscle during exercise, well before any possible changes in gene expression. A similar response has been demonstrated for VEGF-A (20), in which a higher interstitial level was observed during a single exercise bout (21). Such increase must be assumed to reflect an increase in bioavailability also described for other growth factors driven by exercise (22). In fact, exercise activates extracellular proteases (20) known to release bound growth factors through extracellular matrix degradation or binding proteins (23-25). Thus, an increase in available EPO in the skeletal muscle tissue is one possible mechanism behind our observed activation of EPOR with exercise.

The time points for biopsy sampling in the present study were selected mainly to explore EPOR-activation and therefore the last biopsy was taken as early as $2 \mathrm{~h}$ following exercise, thereby analysis of the EPOR associated gene activation was limited. Still, in addition to activation of the receptor, exercise induced an increase in the amounts of EPOR transcripts. Observations using hypoxic neuronal cells show that higher EPOR levels increase the sensitivity to EPO and enhance protection against hypoxia-induced changes $(26,27)$ and provide a plausible biological explanation for this response. Activation of EPOR leads to an enhanced gene expression for the receptor (28), but other factors have been reported to stimulate EPOR transcription. For instance, the hypoxia sensitive transcription factor hypoxia inducible factor-1 and cytokines, such as tumour necrosis factor- $\alpha$, stimulate EPOR gene transcription (29-31) and at least the latter factor is known to become activated by a single bout of exercise (32). Furthermore, a commonly described phenomenon is that EPOR activation induce transcription of the VEGF-A gene, which stimulates angiogenesis (3-5, 33-35). Changes in VEGF-A transcription are known to occur in the $0-2 \mathrm{~h}$ time span following exercise and in fact, an increased VEGF-A transcript level was observed in the present material. Thus, a plausible process of EPOR activation in skeletal muscle is exerciseinduced angiogenesis. However, numerous other factors have been suggested to activate VEGF-A transcription with exercise $(32,36,37)$ and the hypothesis that EPO is angiogenic in resting muscle was recently tested but not supported (18). Still, this does not exclude a role of EPOR activation in exercise-induced angiogenesis. Another alternative process for EPOR activation in skeletal muscle is protection against apoptosis induced by reversible ischemia by activation of the antiapoptotic factors $\mathrm{Bcl}-2$ and $\mathrm{Bcl}-\mathrm{XL}$ (3-5). However, expression changes of these factors are demonstrated to occur days after repetitive exercise bouts (38). All together 
the present study encourages further elaborating of EPOR regulated gene expression in the human skeletal muscle.

In conclusion, the identification of EPOR protein in skeletal muscle fibers and satellite cells, the exerciseinduced increase in muscle EPOR mRNA and the increased EPOR-associated JAK2 phosphorylation together suggests that the EPOR system could play a role in skeletal muscle tissue remodeling. The present findings encourage future studies aiming to establish if there is a relationship between EPOR activation and angiogenesis and/or apoptotic defense in exercising muscle.

\section{Declaration of interest}

The authors declare that there is no conflict of interest that could be perceived as prejudicing the impartiality of the research reported.

\section{Funding}

This work was supported by the Swedish Research Council, the Swedish National Centre for Research in Sports, the Swedish Society of Medicine, the Stockholm County Council, Public Health and Medical Services, Swedish Society for Medical Research and the Magn. Bergvall Foundation.

\section{References}

1 Krantz SB. Erythropoietin. Blood 199177 419-434.

2 Ratajczak J, Majka M, Kijowski J, Baj M, Pan ZK, Marquez LA, Janowska-Wieczorek A \& Ratajczak MZ. Biological significance of MAPK, AKT and JAK-STAT protein activation by various erythropoietic factors in normal human early erythroid cells. British Journal of Haematology 2001115 195-204.

3 Arcasoy MO. The non-haematopoietic biological effects of erythropoietin. British Journal of Haematology 2008141 14-31.

4 Lappin TR, Maxwell AP \& Johnston PG. EPO's alter ego: erythropoietin has multiple actions. Stem Cells 200220 485-492.

5 Marzo F, Lavorgna A, Coluzzi G, Santucci E, Tarantino F, Rio T, Conti E, Autore C, Agati L \& Andreotti F. Erythropoietin in heart and vessels: focus on transcription and signalling pathways. Journal of Thrombosis and Thrombolysis $2008 \mathbf{2 6} 183-187$.

6 Watowich SS. Activation of erythropoietin signaling by receptor dimerization. International Journal of Biochemistry and Cell Biology 199931 1075-1088.

7 Brines M, Grasso G, Fiordaliso F, Sfacteria A, Ghezzi P, Fratelli M, Latini R, Xie QW, Smart J, Su-Rick CJ, Pobre E, Diaz D, Gomez D, Hand C, Coleman T \& Cerami A. Erythropoietin mediates tissue protection through an erythropoietin and common beta-subunit heteroreceptor. PNAS 2004101 14907-14912.

8 Blake TJ, Jenkins BJ, D'Andrea RJ \& Gonda TJ. Functional crosstalk between cytokine receptors revealed by activating mutations in the extracellular domain of the beta-subunit of the GM-CSF receptor. Journal of Leukocyte Biology 200272 1246-1255.

9 Gustafsson T \& Kraus WE. Exercise-induced angiogenesis-related growth and transcription factors in skeletal muscle, and their modification in muscle pathology. Frontiers in Bioscience 20016 D75-D89.

10 Hudlicka O, Brown M \& Egginton S. Angiogenesis in skeletal and cardiac muscle. Physiological Reviews 199272 369-417.

11 Saltin B \& Gollnick PD. Skeletal muscle adaptability: significance for metabolism and performance. In Handbook of Physiology, pp 555-631. Eds LD Peachey, RH Adrian \& SR Geiger, Bethesda, MA: The American Physiological Society, 1983.
12 Phaneuf S \& Leeuwenburgh C. Apoptosis and exercise. Medicine and Science in Sports and Exercise 200133 393-396.

13 Siu PM, Bryner RW, Martyn JK \& Alway SE. Apoptotic adaptations from exercise training in skeletal and cardiac muscles. FASEB Journal 200418 1150-1152.

14 Gunga HC, Kirsch KA, Roecker L, Kohlberg E, Tiedemann J, Steinach M \& Schobersberger W. Erythropoietin regulations in humans under different environmental and experimental conditions. Respiratory Physiology \& Neurobiology 2007158 287-297.

15 Roecker L, Kowoll R, Fraszl W, Battal K, Brechtel L, Brachmann S, Meier-Buttermilch R, Gunga HC, Stangl A \& Kiesewetter H. Observation of serum erythropoietin concentrations in female athletes for up to eight days after a marathon run. Clinical Laboratory $2006 \mathbf{5 2} 511-513$.

16 Schwandt HJ. Heyduck B, Gunga HC \& Rocker L. Influence of prolonged physical exercise on the erythropoietin concentration in blood. European Journal of Applied Physiology and Occupational Physiology 199163 463-466.

17 Ogilvie M, Yu X, Nicolas-Metral V, Pulido SM, Liu C, Ruegg UT \& Noguchi CT. Erythropoietin stimulates proliferation and interferes with differentiation of myoblasts. Journal of Biological Chemistry 2000275 39754-39761.

18 Lundby C, Hellsten Y, Jensen MB, Munch AS \& Pilegaard H. Erythropoietin receptor in human skeletal muscle and the effects of acute and long-term injections with recombinant human erythropoietin on the skeletal muscle. Journal of Applied Physiology 2008104 1154-1160.

19 Anagnostou A, Liu Z, Steiner M, Chin K, Lee ES, Kessimian N \& Noguchi CT. Erythropoietin receptor mRNA expression in human endothelial cells. PNAS 199491 3974-3978.

20 Rullman E, Rundqvist H, Wagsater D, Fischer H, Eriksson P, Sundberg CJ, Jansson E \& Gustafsson T. A single bout of exercise activates matrix metalloproteinase in human skeletal muscle. Journal of Applied Physiology 2007102 2346-2351.

21 Hoffner L, Nielsen JJ, Langberg H \& Hellsten Y. Exercise but not prostanoids enhance levels of vascular endothelial growth factor and other proliferative agents in human skeletal muscle interstitium. Journal of Physiology $2003 \mathbf{5 5 0}$ 217-225.

22 Berg U, Gustafsson T, Sundberg CJ, Kaijser L, Carlsson-Skwirut C \& Bang P. Interstitial IGF-I in exercising skeletal muscle in women. European Journal of Endocrinology 2007 157 427-435.

23 Coppock HA, White A, Aplin JD \& Westwood M. Matrix metalloprotease-3 and -9 proteolyze insulin-like growth factorbinding protein-1. Biology of Reproduction 200471 438-443.

24 Bergers G, Brekken R, McMahon G, Vu TH, Itoh T, Tamaki K, Tanzawa K, Thorpe P, Itohara S, Werb Z \& Hanahan D. Matrix metalloproteinase-9 triggers the angiogenic switch during carcinogenesis. Nature Cell Biology 20002 737-744.

25 Lee S, Jilani SM, Nikolova GV, Carpizo D \& Iruela-Arispe ML. Processing of VEGF-A by matrix metalloproteinases regulates bioavailability and vascular patterning in tumors. Journal of Cell Biology 2005169 681-691.

26 Chin K, Yu X, Beleslin-Cokic B, Liu C, Shen K, Mohrenweiser HW \& Noguchi CT. Production and processing of erythropoietin receptor transcripts in brain. Brain Research. Molecular Brain Research 2000 $8129-42$.

27 Yu X, Shacka JJ, Eells JB, Suarez-Quian C, Przygodzki RM, Beleslin-Cokic B, Lin CS, Nikodem VM, Hempstead B, Flanders KC, Costantini F \& Noguchi CT. Erythropoietin receptor signalling is required for normal brain development. Development $2002129505-516$.

28 Beleslin-Cokic BB, Cokic VP, Yu X, Weksler BB, Schechter AN \& Noguchi CT. Erythropoietin and hypoxia stimulate erythropoietin receptor and nitric oxide production by endothelial cells. Blood $20041042073-2080$.

29 Yoon D, Pastore YD, Divoky V, Liu E, Mlodnicka AE, Rainey K, Ponka P, Semenza GL, Schumacher A \& Prchal JT. Hypoxiainducible factor- 1 deficiency results in dysregulated erythropoiesis signaling and iron homeostasis in mouse development. Journal of Biological Chemistry $200628125703-25711$. 
30 Shein NA, Horowitz M, Alexandrovich AG, Tsenter J \& Shohami E. Heat acclimation increases hypoxia-inducible factor 1alpha and erythropoietin receptor expression: implication for neuroprotection after closed head injury in mice. Journal of Cerebral Blood Flow and Metabolism 200525 1456-1465.

31 Nagai A, Nakagawa E, Choi HB, Hatori K, Kobayashi S \& Kim SU. Erythropoietin and erythropoietin receptors in human CNS neurons, astrocytes, microglia, and oligodendrocytes grown in culture. Journal of Neuropathology and Experimental Neurology 2001 $60386-392$.

32 Ameln H, Gustafsson T, Sundberg CJ, Okamoto K, Jansson E, Poellinger L \& Makino Y. Physiological activation of hypoxia inducible factor-1 in human skeletal muscle. FASEB Journal 2005 19 1009-1011.

33 Ribatti D, Presta M, Vacca A, Ria R, Giuliani R, Dell'Era P, Nico B, Roncali L \& Dammacco F. Human erythropoietin induces a proangiogenic phenotype in cultured endothelial cells and stimulates neovascularization in vivo. Blood 199993 2627-2636.

34 Jaquet K, Krause K, Tawakol-Khodai M, Geidel S \& Kuck KH. Erythropoietin and VEGF exhibit equal angiogenic potential. Microvascular Research 200264 326-333.
35 Nakano M, Satoh K, Fukumoto Y, Ito Y, Kagaya Y, Ishii N, Sugamura K \& Shimokawa H. Important role of erythropoietin receptor to promote VEGF expression and angiogenesis in peripheral ischemia in mice. Circulation Research $2007 \mathbf{1 0 0}$ 662-669.

36 Arany Z, Foo SY, Ma Y, Ruas JL, Bommi-Reddy A, Girnun G, Cooper M, Laznik D, Chinsomboon J, Rangwala SM, Baek KH, Rosenzweig A \& Spiegelman BM. HIF-independent regulation of VEGF and angiogenesis by the transcriptional coactivator PGC-1alpha. Nature $2008 \mathbf{4 5 1} 1008-1012$.

37 Milkiewicz M, Brown MD, Egginton S \& Hudlicka O. Association between shear stress, angiogenesis, and VEGF in skeletal muscles in vivo. Microcirculation $20018229-241$.

38 Podhorska-Okolow M, Sandri M, Zampieri S, Brun B, Rossini K \& Carraro U. Apoptosis of myofibres and satellite cells: exerciseinduced damage in skeletal muscle of the mouse. Neuropathology and Applied Neurobiology 199824 518-531.

Received 22 May 2009

Accepted 22 May 2009 